\title{
Rapid Biosynthesis of Gold Nanoparticles by the Extracellular Secretion of Bacillus niabensis 45: Characterization and Antibiofilm Activity
}

\author{
Yumei Li, Yamei Li, Qiang Li, Xiangyu Fan, Juan Gao, and Yan Luo \\ School of Biological Science and Biotechnology, University of Jinan, Jinan, China \\ Correspondence should be addressed to Yumei Li; mls_liym@ujn.edu.cn
}

Received 19 May 2016; Accepted 21 July 2016

Academic Editor: Roberto Comparelli

Copyright (c) 2016 Yumei Li et al. This is an open access article distributed under the Creative Commons Attribution License, which permits unrestricted use, distribution, and reproduction in any medium, provided the original work is properly cited.

The present study demonstrated that the extracellular biosynthesis of gold nanoparticles (GNPs) using B. niabensis 45 may be mediated by a cyclic peptide (P2). The molecular weight of P2 was determined to be about 1122 Da by MALDI-TOF-MS and ESI-MS A novel protocol for rapid biosynthesis of GNPs using P2 was developed. The results showed that GNP synthesis could be completed in a wide range of temperatures $\left(40-100^{\circ} \mathrm{C}\right)$ and $\mathrm{pH}(6.0-10.0)$ within few minutes when $9 \mathrm{~mL}$ of $\mathrm{P} 2(2 \mathrm{mg} / \mathrm{mL})$ and $1 \mathrm{~mL}$ of $\mathrm{HAuCl}_{4}$ solution $(2 \mathrm{mM})$ were mixed together. The synthesized GNPs were further characterized. Energy dispersive spectroscopy (EDS) and X-ray diffraction (XRD) analysis confirmed the presence of elemental gold and crystalline structure of the GNPs, respectively. Scanning electron microscopy (SEM) and transmission electron microscopy (TEM) revealed the formation of spherical metallic GNPs. The size distribution of GNPs calculated using ImageJ software was found to be 10-20 nm. And these GNPs showed excellent antibiofilm activity against Pseudomonas aeruginosa PAO1 and Staphylococcus aureus ATCC25923. The results revealed microbial cyclic peptides could be used as synthesis of GNPs which had potent antibiofilm potential.

\section{Introduction}

Gold nanoparticles (GNPs) have unique optical, electrical, and photothermal properties [1]. They have been extensively employed in biomedical field in the last decade like drug delivery, imaging, and treatment of major life threatening diseases [2,3]. Nevertheless, experimental use of GNPs presented possible medical hazards which could threaten human health because of their surface properties [4]. So there is an urgent need to develop safe, clean, nontoxic, and environment-friendly method of GNP synthesis. Biological approaches are available for synthesis of GNPs. Biosynthesized GNPs are frequently attached to a biological carrier or scaffold and many feature biogenic capping materials that enhance the compatibility and stability of GNPs under environmental conditions. Several bacteria, actinomycetes, fungi, and plants exhibit the excellent ability to produce GNPs intracellularly and/or extracellularly [5]. The shape and size of the GNPs synthesized by the biological systems can be affected by some parameters such as $\mathrm{pH}$, temperature, substrate concentrations, and reaction time [6].

Although great many reports focus on microbial synthesis of GNPs, the mechanistic aspects have not been clarified and the active ingredients controlling GNP synthesis need to be studied in depth [7-9]. Such studies have been performed to isolate the active ingredient and explain the mechanism underlying GNP synthesis. The organic phosphate compounds from B. subtilis 168 may be as bacteria-Au complexing agents to lead to the formation of GNPs [7]. The species specific NADH dependent reductases from Fusarium oxysporum and Rhodopseudomonas capsulate could mediate bioreduction of $\mathrm{Au}^{3+}$ ions to carry out the synthesis of GNPs [8-10]. The lignolytic enzymes such as laccase and ligninase from Phanerochaete chrysosporium were reported to synthesize extracellular and intracellular GNP synthesis [11]. In addition, the proteins, polysaccharides, and organic acids released by the fungi are able to participate in producing GNPs [12]. 
GNPs have attracted great scientific interest as a new alternative of antimicrobial agents due to the increase of antibiotic resistance traits in bacteria and other pathogens. They inhibit the growth of bacteria through collapsing cell membrane or interfering binding of tRNA to the ribosome submit, which make it very difficult for bacteria to acquire resistance against them [13].

In this study, a novel bacterial strain, identified as Bacillus niabensis 45, was able to synthesize GNPs from this strain's extracellular secretion. The mechanism and the optimal parameters for GNP synthesis were investigated. And the resulting GNPs were characterized by SEM-EDS, TEMSAED, and XRD, whose antibiofilm activity was assayed.

\section{Materials and Methods}

2.1. Bacterial Strain and Cultivation. Bacillus niabensis 45 was identified by analyzing its morphologic characteristics, biochemical and physiological properties, and the $16 \mathrm{~S}$ rDNA sequence (GenBank accession number: KT962921).

The bacterial strain was grown in starch-casein broth containing $10 \mathrm{~g} / \mathrm{L}$ starch, $0.3 \mathrm{~g} / \mathrm{L}$ casein, $2 \mathrm{~g} / \mathrm{L} \mathrm{KNO}_{3}, 2 \mathrm{~g} / \mathrm{L}$ $\mathrm{KH}_{2} \mathrm{PO}_{4}, \quad 0.5 \mathrm{~g} / \mathrm{L} \quad \mathrm{MgSO}_{4} \cdot 7 \mathrm{H}_{2} \mathrm{O}, 0.02 \mathrm{~g} / \mathrm{L} \quad \mathrm{CaCO}_{3}$, and $0.001 \mathrm{~g} / \mathrm{L} \mathrm{FeSO}_{4}$. Culture was incubated at $28^{\circ} \mathrm{C}$ for $72 \mathrm{~h}$ with shaking at $150 \mathrm{rpm}$.

2.2. Biosynthesis of GNPs. The fermentation broth of $B$. niabensis 45 was centrifuged at $12,000 \mathrm{~g}$ for $20 \mathrm{~min}$. The resulting supernatant was filtered using $0.22 \mu \mathrm{m}$ cellulose membrane. The filtrate was mixed with $2 \mathrm{mM}$ of $\mathrm{HAuCl}_{4}$ solution $(9: 1, \mathrm{v} / \mathrm{v})$ and incubated at $37^{\circ} \mathrm{C}$ in a rotary shaker. The formation of GNPs was determined by color change and the reduction of gold ions was confirmed by UV-vis spectra observed in the range of 500-600 $\mathrm{nm}[14,15]$.

2.3. Determination of Active Ingredient. The cell-free supernatant was treated with the methods of ammonium sulfate precipitation, ethyl acetate extraction, and hydrochloric acid precipitation. The ammonium sulfate precipitation was performed by adding $20 \%-80 \%$ saturated ammonium sulfate solution to the cell-free supernatant to yield the proteins. The resulting proteins were dissolved and dialyzed using deionized water and then applied to GNP synthesis. The acetate extraction was carried out by adding the equal volume proportion of ethyl acetate to the cell-free supernatant to obtain low polar constituents; then the organic phase was isolated and evaporated to dryness at $40^{\circ} \mathrm{C}$ using a rotary evaporator. The extract was dissolved in deionized water and used for GNP synthesis. The hydrochloric acid precipitation was achieved by adjusting the $\mathrm{pH}$ of the cell-free supernatant to 2.0 using $6 \mathrm{M}$ hydrochloric acid under ice bath condition. After storing at $4^{\circ} \mathrm{C}$ for $12 \mathrm{~h}$, the precipitate was extracted three times with acetone. The extracts were pooled and evaporated to dryness at $30^{\circ} \mathrm{C}$ to the crude peptides.

The crude peptides were dissolved in 50\% aqueous acetonitrile/0.1 trifluoroacetic acid and applied to highperformance liquid chromatography (HPLC) equipped with a variable wavelength absorbance detector set at $214 \mathrm{~nm}$ (Agilent 1200, VWD) and a Shim-pack PREP-ODS C18 column $(46 \times 150 \mathrm{~mm}, 3.5 \mu \mathrm{m}$, Agilent, USA). A linear 10 to $90 \%$ acetonitrile gradient was used for elution at flow rate of $1 \mathrm{~mL}$ for $20 \mathrm{~min}$. Eluent A consisted of $80 \%$ acetonitrile with $0.1 \%$ trifluoroacetic acid, and eluent B was composed of deionized water with $0.1 \%$ trifluoroacetic acid. All the HPLC fractions were collected separately and their activities were further assayed for GNP synthesis. The peak with the highest activity of GNP synthesis was selected for MALDITOF-MS and ESI-MS analysis [16]. The purified peptide was hydrolyzed by $6 \mathrm{M} \mathrm{HCl}$ for $2 \mathrm{~h}$ at $110^{\circ} \mathrm{C}$. The hydrolyzed products were applied to thin-layer chromatography (TLC) to detect the amino groups [16].

2.4. Optimization of Parameters. The ratio of peptide $(2 \mathrm{mg} / \mathrm{mL})$ and $\mathrm{HAuCl}_{4}(2 \mathrm{mM})$ which was kept in the ranges of $9: 1,8: 2,3: 7,4: 6$, and $5: 5(\mathrm{v} / \mathrm{v})$ was used to find out the optimum dosage of peptide and $\mathrm{HAuCl}_{4}$. The temperature of the reaction was investigated by incubating at $30^{\circ} \mathrm{C}, 40^{\circ} \mathrm{C}$, $50^{\circ} \mathrm{C}, 60^{\circ} \mathrm{C}, 70^{\circ} \mathrm{C}, 90^{\circ} \mathrm{C}$, and $100^{\circ} \mathrm{C}$. The effect of $\mathrm{pH}$ on GNP synthesis was evaluated at $\mathrm{pH}$ of 4.0, 5.0, 6.0, 7.0, 8.0, 9.0, 10.0 , and 11.0. The $\mathrm{pH}$ was maintained using $1 \mathrm{M} \mathrm{HCl}$ and $1 \mathrm{M}$ $\mathrm{NaOH}$. The production of GNPs was detected at various time intervals using UV-vis spectrophotometry (Agilent 8453, USA) with a resolution of $1.0 \mathrm{~nm}$ between 400 and $800 \mathrm{~nm}$.

2.5. Characterization of GNPs. The formation of GNPs was monitored by a UV-visible spectrophotometer from 200 to $800 \mathrm{~nm}$. The synthesized GNPs were separated by centrifugation and used for X-ray diffraction (XRD) analysis. XRD patterns were collected in the range of $20-80^{\circ} \mathrm{C}(2 \theta)$ operated at $40 \mathrm{kV}$ and $30 \mathrm{~mA}$ (EXPLORER, GNR, Italy). The morphological analysis was performed by high-resolution transmission electron microscope (HR-TEM, JEOL JSM 100CX, Japan) at an accelerating voltage of $200 \mathrm{kV}$. Selected area electron diffraction (SAED) of GNPs was also analyzed using TEM. Particle size distribution was calculated for the synthesized nanoparticles by averaging 100 particles from TEM images using ImageJ software (https://imagej.nih.gov/ij/).

2.6. Assay of Antibiofilm Activity. The antibiofilm activity of GNPs against $P$. aeruginosa PAO1 and $S$. aureus ATCC 25923 was assayed as described in our previous study [17]. Briefly, the bacterial strains were grown at $37^{\circ} \mathrm{C}$ in Brain Heart Infusion (BHI) broth. The culture was diluted at 1:200 in fresh BHI broth containing various concentrations of GNPs (2048, 256, and $32 \mu \mathrm{g} /$ well) and dispensed in sub-200 $\mu \mathrm{L}$ volumes into a 96-well microtiter plate. The plates were incubated at $37^{\circ} \mathrm{C}$ for $36 \mathrm{~h}$. The cell growth was monitored at set intervals in $24 \mathrm{~h}$ using a microtiter plate reader at $600 \mathrm{~nm}$. Then the residual medium in the plates was removed and the wells were washed by distilled water for three times. After drying, the attached cells were stained with $200 \mu \mathrm{L}$ of crystal violet solution $(1 \%, \mathrm{w} / \mathrm{v})$ for $10 \mathrm{~min}$. Subsequently, the crystal violet was removed and the plates were washed by distilled water for three times. The biofilm formation was recorded by micrograph. After photographing, the stained cells were destained using ethanol-acetone solution $(4: 1)$ to the wells. The medium without GNPs was used as a positive 
control. Biofilm formation was determined by measuring the absorbance at $570 \mathrm{~nm}\left(A_{570 \mathrm{~nm}}\right)$ using a microtiter plate reader. All the experiments were carried out in triplicate. The antibiofilm activity was described by the percentage of biofilm inhibition, which was calculated as follows: biofilm inhibition $(\%)=\left[1-\left(A_{\text {sample }}-A_{\text {control }}\right)\right] \times 100$.

\section{Results and Discussion}

3.1. Extracellular Biosynthesis of GNPs. The bottle containing the cell-free filtrate and $\mathrm{HAuCl}_{4}$ solution showed gradual change in color of reaction mixture from colorless to wine red with intensity increasing during the incubation period. The negative control containing starch-casein medium and $\mathrm{HAuCl}_{4}$ solution did not show the characteristic change in color (Figure 1(a)). UV-vis spectra of the reaction mixture showed a shift of peak maxima from $528 \mathrm{~nm}$ to $558 \mathrm{~nm}$ with the increase of reaction time, and the maximum intensity was observed at $528 \mathrm{~nm}$ after $30 \mathrm{~min}$ (Figure 1(b)). Then no further change in spectra was recorded indicating completed reduction of gold ions by the filtrate. The change in the shift of peak may be possible due to variation in shape and size of GNPs [18].

\subsection{Active Ingredient and Mechanism Perspective for GNP} Synthesis. After treatment with the cell-free extract of $B$. niabensis 45 using different methods, only the peptide solution from hydrochloric acid precipitation exhibited an ability of GNP synthesis. This meant that peptides may be active ingredient in supernatant of $B$. niabensis 45 for biosynthesis of GNPs. Then the possible crude peptide solution was applied to PREP-HPLC. Two main peaks (P1 and P2) were separated and used to assay the activity of GNP synthesis (Figure 2(a)). It was found that only peak P2 could synthesize GNPs. The molecular weight of P2 was determined by MALDI-TOFMS. The protonated molecular ion $(\mathrm{M}+\mathrm{H})^{+}$peak of $\mathrm{P} 2$ was detected as 1123.22; it indicated that the molecular weight of P2 was $1122 \mathrm{Da}$ (Fig. Sla in Supplementary Material available online at http://dx.doi.org/10.1155/2016/2781347). Then P2 was further detected by ESI-MS. The full scan spectrum gave single, double, and ternary protonated molecular ion at $m / z 1123.4(\mathrm{M}+\mathrm{H})^{+}, 561.8(\mathrm{M}+2 \mathrm{H}) 2^{+}$, and $375.0(\mathrm{M}$ $+3 \mathrm{H}) 3^{+}$, respectively (Fig. S1b). The results are consistent with the molecular weight obtained from MALDI-TOF-MS. TLC assay of P2 showed that the colorized dots appeared at TLC plates sprayed with ninhydrin after hydrochloric acid hydrolysis, which indicate the presence of the free amino groups. But no dots were observed without acid hydrolysis. These results indicated that the compound P2 may be a cyclic peptide (Figure 2(b)).

The previous studies have revealed that amino acids and oligopeptides could act as reducing and capping agents for GNPs [19]. Based on these reports, proteins and amino acid residues in peptide such as cysteine, tyrosine, and tryptophan were found to play an important role in biosynthesis and stabilization of GNPs [20-22]. Tryptophan can produce metal NPs at basic $\mathrm{pH}$ by providing an electron from a transient trypophyl radical due to conversion of tryptophan residue present in peptide [22]. In addition, it was recently reported

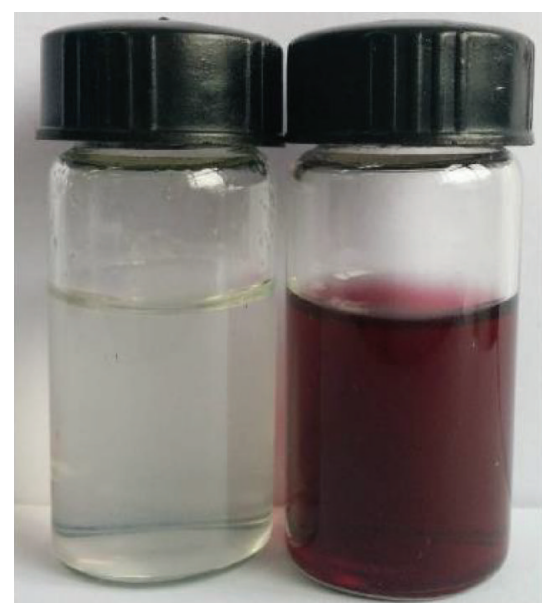

(a)

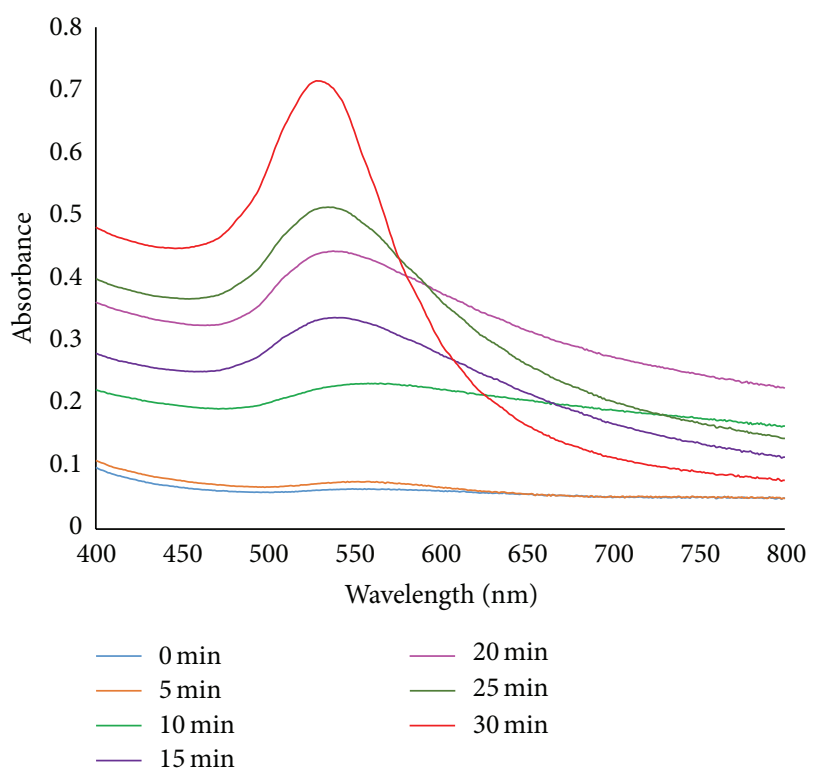

(b)

Figure 1: (a) Cell-free filtrate of B. niabensis 45 (left) and biosynthesized GNPs using cell-free filtrate of $B$. niabensis 45 (right). (b) UV-vis spectra of GNPs at different reaction time intervals.

that peptide containing histidine and tyrosine can mediate synthesis of silver nanoparticles (AgNPs) by electron transfer in the presence of chloride ions. In this process, histidine could bind $\mathrm{Ag}^{+}$by its imidazole group to form $\mathrm{Ag}^{+}$-peptides. The tyrosine was used as an electron donor. The chloride ions could facilitate electron transfer-induced synthesis of AgNPs from $\mathrm{Ag}^{+}$-peptides by assembling $\mathrm{Ag}^{+}$into $\mathrm{AgCl}$ microcrystals [23]. Similarly, the mechanism on rapid biosynthesis of GNPs using the peptide from B. niabensis 45 may be proposed as follows: the amphiprotic peptide will present the negative charge of $\mathrm{COO}^{-}$group, which was in favor of the formation of $\mathrm{Au}^{3+}$-peptide complex. Then tyrosine or tryptophan in peptides possibly provides electrons to reduce $\mathrm{Au}^{3+}$ ions to $\mathrm{Au}^{0}$ atoms. Furthermore, GNPs may be synthesized by the aggregation of $\mathrm{Au}^{0}$ atoms. 


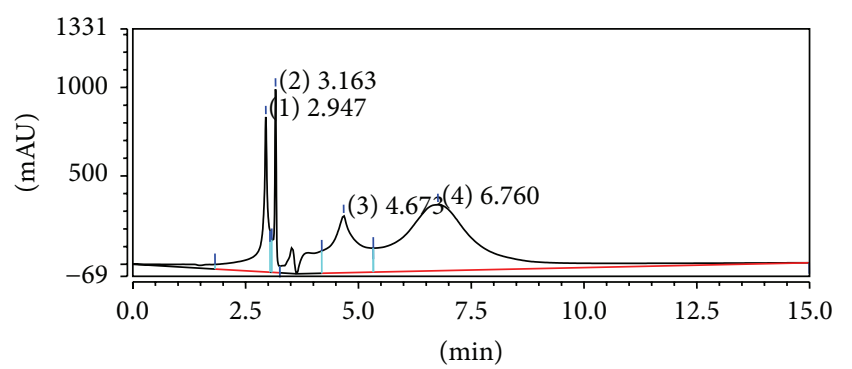

(a)

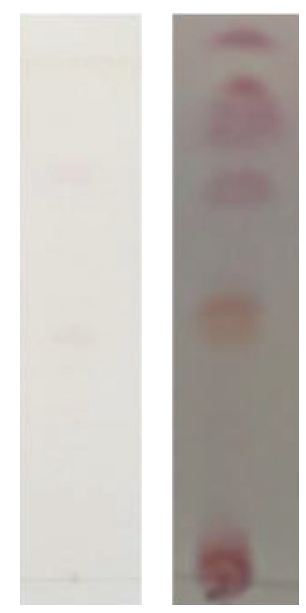

(b)

FIgURE 2: (a) PREP-HPLC profile of the crude peptides from $B$. niabensis 45. (b) TLC chromatogram of peak P2 before (left) and after (right) hydrochloric acid hydrolysis.

3.3. Optimization of Parameters for GNP Synthesis. The purified peptide $\mathrm{P} 2$ was used to produce GNPs and the optimum parameters of GNP synthesis were investigated. The ratio of $9 \mathrm{~mL}$ peptide $\mathrm{P} 2(2 \mathrm{mg} / \mathrm{mL})$ along with $1 \mathrm{~mL} \mathrm{HAuCl}_{4}(2 \mathrm{mM})$ showed a characteristic peak at $520 \mathrm{~nm}$, whereas no formation of GNPs occurred or the formation of GNPs was unstable at other concentration ratios. The effect of temperature on GNP synthesis was shown in Figure 3(a); the color of the reaction solution containing peptide $\mathrm{P} 2$ and $\mathrm{HAuCl}_{4}$ turned to be wine red from colorless within 2 min when the incubated temperature was more than $40^{\circ} \mathrm{C}$. UV-vis spectra of the product solution were recorded after $2 \mathrm{~min}$. The maximum absorption peak shifted to $528 \mathrm{~nm}$ from $520 \mathrm{~nm}$ with the increase of the incubation temperature, and the corresponding peak intensity occurred at $100^{\circ} \mathrm{C}$. These results suggested the potential of rapid biosynthesis using peptide P2 from B. niabensis 45 at a higher temperature. Some reports have indicated that the rate of GNP synthesis increased with an increase in reaction temperature due to increase of activation energy and reducing power of the biological moieties [24].

The ability of peptide P2 to synthesize GNPs was evaluated in the range of $\mathrm{pH}$ from 4.0 to 11.0 at $40^{\circ} \mathrm{C}$. In this case, the rapid biosynthesis of GNPs was observed in a wide $\mathrm{pH}$ range of 6.0-10.0 within $5 \mathrm{~min}$ (Figure 3(b)). Because the peptide was amphoteric, its carboxylic groups will be protonated when the solution $\mathrm{pH}$ is less than isoelectric point (PI)

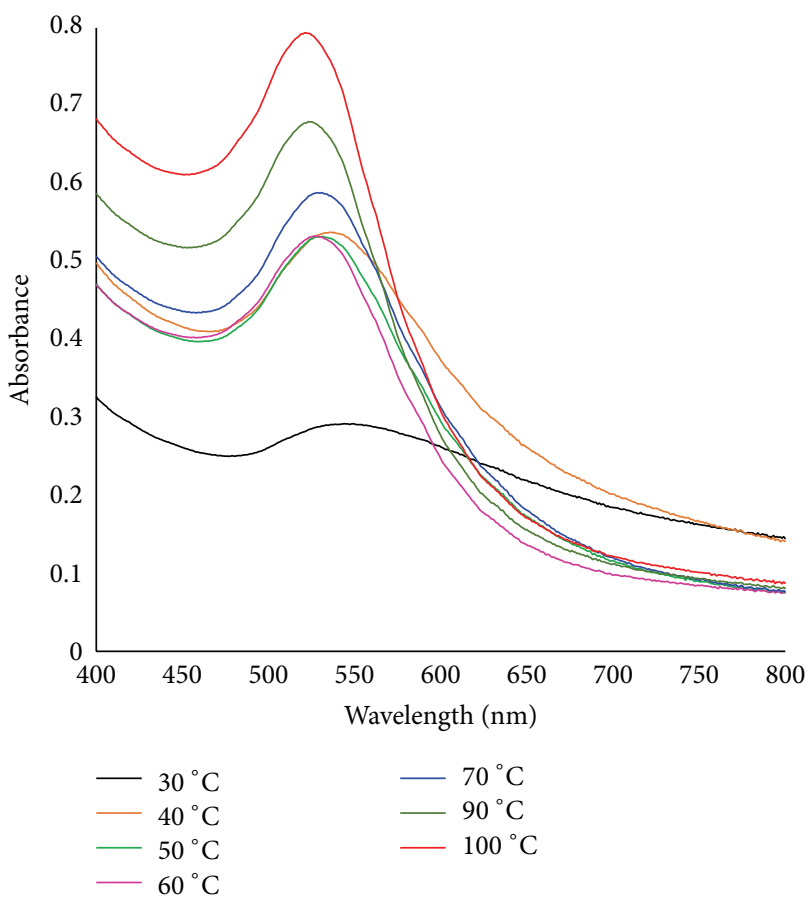

(a)

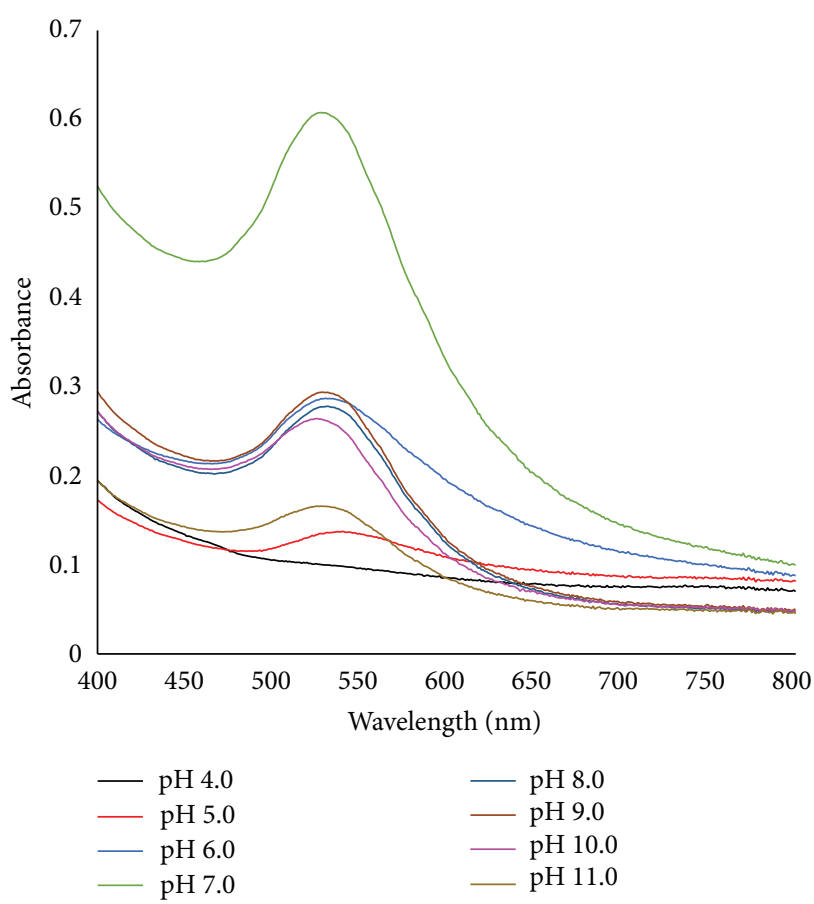

(b)

FIGURE 3: The effects of temperature (a) and $\mathrm{pH}(\mathrm{b})$ on synthesis of GNPs by peptide $\mathrm{P} 2$.

of the peptide, and the electrostatic repulsion cannot impart stability to particles in solution, leading to either no synthesis or instability to the particles. On the contrary, the carboxylic groups will be ionized to $\mathrm{COO}^{-}$when the solution $\mathrm{pH}$ is more than PI of the peptide. The negative charge of carboxylic 


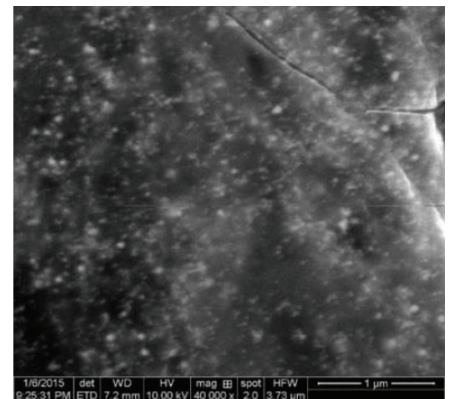

(a)

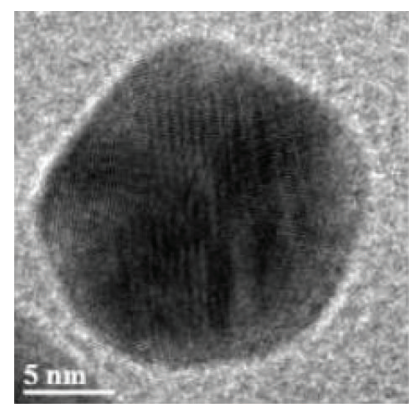

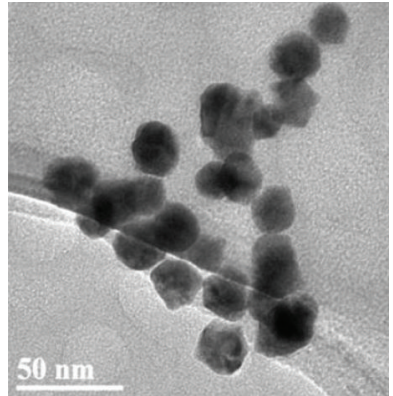

(b)

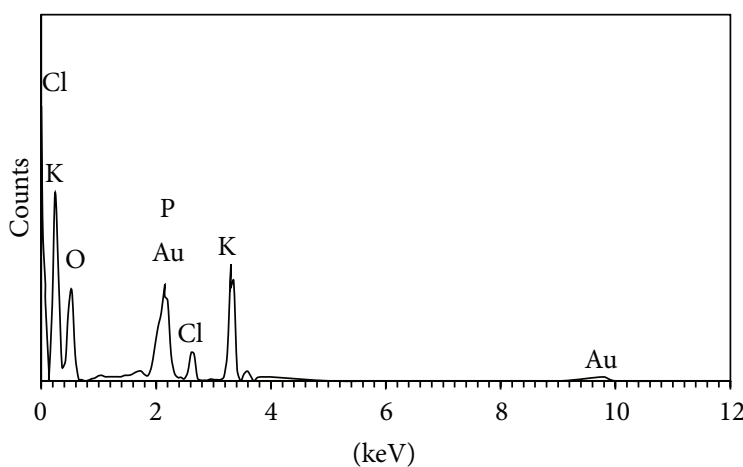

(c)
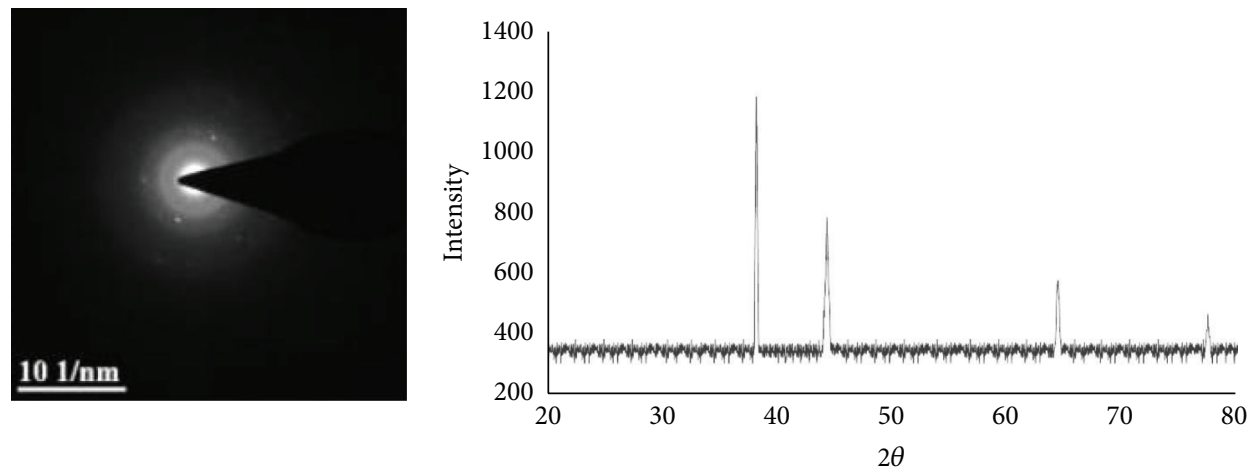

(e)

FIGURE 4: Characterization of GNPs described by SEM (a) and TEM (b) micrograph, ESD spectrum (c), SAED (d), and XRD (e) pattern.

groups would exhibit remarkable binding affinity for $\mathrm{Au}^{3+}$, which may be in favor of reduction of gold ions. In addition, the maximum formation of GNPs was observed at $\mathrm{pH} 7.0$ due to the presence of GNPs being stable under this condition.

3.4. Characterization of GNPs. The SEM image showed that the morphology of GNPs was spherical (Figure 4(a)). TEM micrograph further confirmed the formation of spherical nanoparticles with the size in the range of $10-20 \mathrm{~nm}$ (Figure 4(b)). EDS spectrum confirmed the presence of element gold (Figure 4(c)). SAED patterns for the single particle revealed a characteristic polycrystalline ring pattern for a face-centred-cubic structure (Figure 4(d)). XRD pattern revealed broadening of the intense peaks corresponding to (111), (200), (220), and (311) Bragg reflection at $2 \theta=38.2^{\circ}$, $44.3^{\circ}, 64.4^{\circ}$, and $77.5^{\circ}$, respectively, indicating the formation of crystalline GNPs (Figure 4(e)).

3.5. Antibiofilm Activity. As shown in Figure 5(a), GNPs could reduce the process of biofilm formation against the Gram-positive S. aureus ATCC25923 and the Gram-negative $P$. aeruginosa $\mathrm{PAO1}$ in a dose-dependent manner without affecting cell growth (Figures 6(a) and 6(b)). The highest antibiofilm activity was exhibited against $S$. aureus and $P$. aeruginosa with inhibition percentages of up to $68 \%$ and $72 \%$, respectively (Figure 5(b)). These data mean that GNPs synthesized by the cyclic peptide $\mathrm{P} 2$ have excellent capability of antibiofilm with low toxicity or without toxicity, which may be due to the peptide coating of NPs. Our results were in agreement with the report of Salunke et al., where gold nanoparticles produced by biological extract consisting of proteins could exhibit effective inhibition against biofilm formation of $S$. aureus [25]. In fact, microbial peptides have been a new tool for antibiofilm in recent decades $[26,27]$. Moreover, control of bacterial biofilms using NPs like zinc oxide and silver has attracted significant research interest because of their high surface-to-volume ratio [28-30].

\section{Conclusions}

In this paper, the extracellular synthesis of GNPs by $B$. niabensis 45 was investigated in detail. The active ingredient in the cell-free extract for biosynthesis of GNPs was a cyclic peptide with a molecular weight of $1122 \mathrm{Da}$, which was able to synthesize GNPs through possible electron transfer process. Then a novel protocol for rapid biosynthesis of GNPs using the cyclic peptide was demonstrated and the resulting GNPs were characterized. The biosynthesis of GNPs was obtained when $9 \mathrm{~mL}$ of peptide $\mathrm{P} 2(2 \mathrm{mg} / \mathrm{mL})$ and $1 \mathrm{~mL}$ of $\mathrm{HAuCl}_{4}$ solution $(2 \mathrm{mM})$ were mixed together. This process was facilitated by a high temperature $\left(>40^{\circ} \mathrm{C}\right)$ and a wide $\mathrm{pH}$ range (6.0-10.0), which could significantly shorten the 


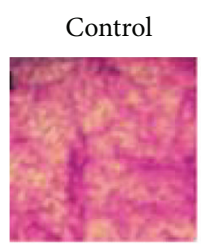

(A)

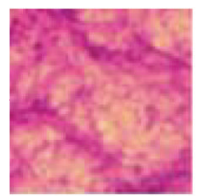

(B)

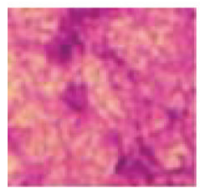

(C)

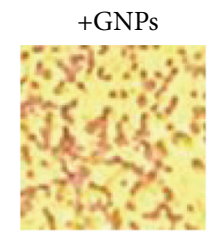

(D)

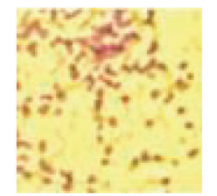

(E)

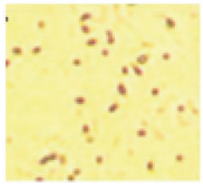

(F)

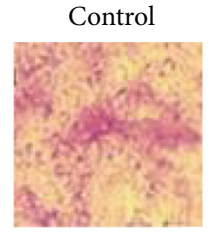

(G)

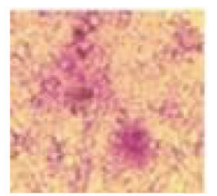

$(\mathrm{H})$

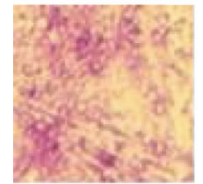

(I)

S. aureus ATCC25923

(a)

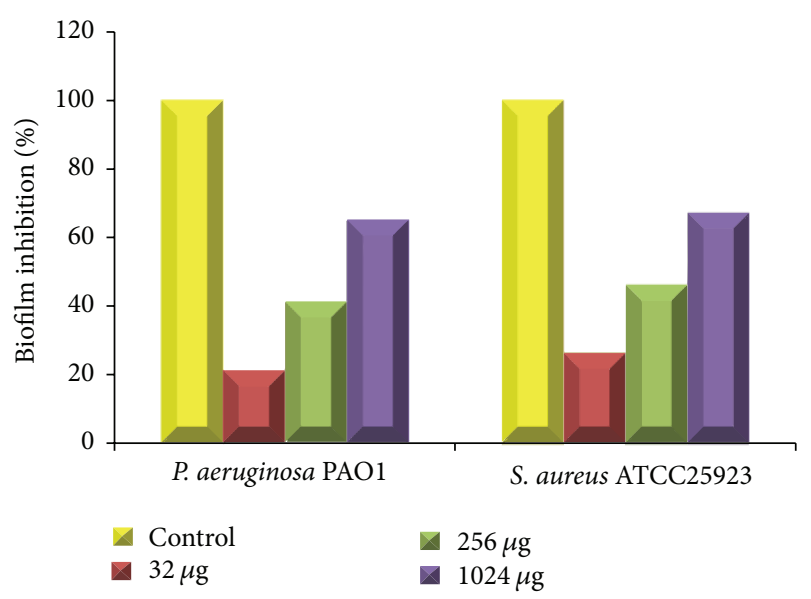

(b)

Figure 5: Micrographs of biofilm formation (a) and biofilm inhibition by different concentrations of GNPs (b).

reaction time to be $2-5 \mathrm{~min}$. In addition, the characterization of GNPs showed that their crystals are face-centred-cubic with a size of $10-20 \mathrm{~nm}$, which showed prominent antibiofilm activity against the tested Gram bacteria.

These results will lay a foundation to clarify the mechanism on microbial synthesis of GNPs and present a novel promising approach for simple and rapid biosynthesis of GNPs using microbial peptides. And the peptide coating of GNPs may be a new tool to combat bacteria biofilm.

\section{Competing Interests}

The authors declare that they have no competing interests.

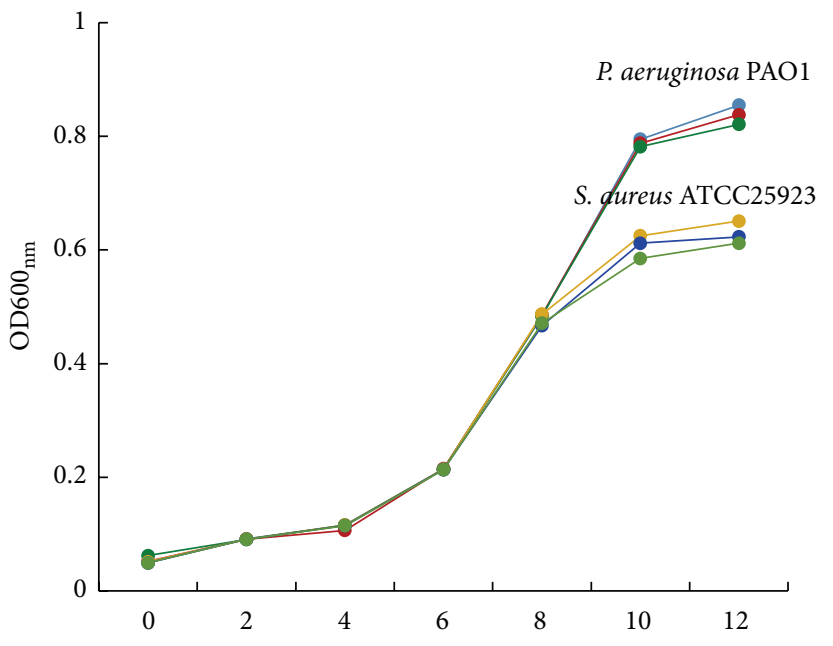

(h)

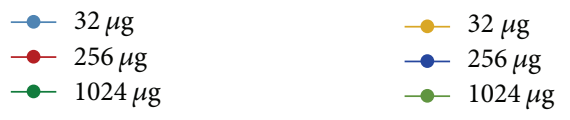

(a)

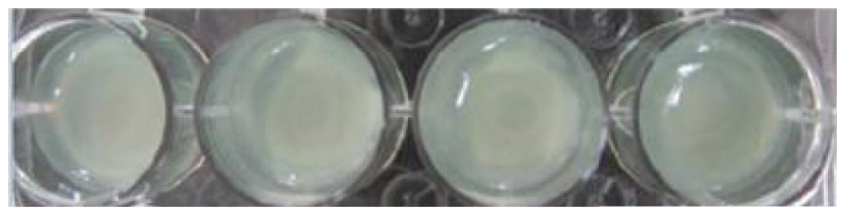

(A)

(B)

(C)

(D)

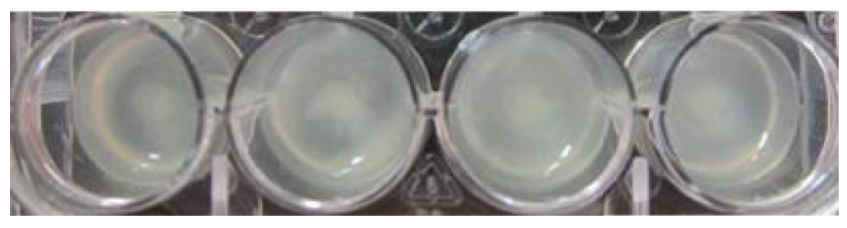

(E)

(F)

(G)

$(\mathrm{H})$

(b)

Figure 6: Growth profiles of the bacterial strains in $12 \mathrm{~h}$ (a). Comparison of cell growth in the presence of different concentrations of GNPs at $12 \mathrm{~h}$ (b). The upper and lower graphs represent cell growth of $P$. aeruginosa PAO1 and $S$. aureus ATCC25923, respectively. The graphs (A) and (E) are positive controls by erythromycin; (B) and $(F),(C)$ and $(G)$, and (D) and (H) represent the presence of 32, 256, and $2024 \mu \mathrm{g}$ of GNPs, respectively.

\section{Acknowledgments}

The authors acknowledge the financial support provided by National Natural Science Foundation of China (Project no. 31300045), a project of Shandong Province Higher Educational Science and Technology Program (YE13), Foundation of University of Jinan (XKY1324, 1422), China Postdoctoral Science Foundation (2015M572018), and Open fund of Xinjiang Production \& Construction Corps Key Laboratory of Protection and Utilization of Biological Resources in Tarim Basinand (BYBR1405). 


\section{References}

[1] S. K. Ghosh and T. Pal, "Interparticle coupling effect on the surface plasmon resonance of gold nanoparticles: from theory to applications," Chemical Reviews, vol. 107, no. 11, pp. 47974862, 2007.

[2] G. Ajnai, A. Chiu, T. Kan, C.-C. Cheng, T.-H. Tsai, and J. Chang, "Trends of gold nanoparticle-based drug delivery system in cancer therapy," Journal of Experimental and Clinical Medicine, vol. 6, no. 6, pp. 172-178, 2014.

[3] X. Qian, X.-H. Peng, D. O. Ansari et al., "In vivo tumor targeting and spectroscopic detection with surface-enhanced Raman nanoparticle tags," Nature Biotechnology, vol. 26, no. 1, pp. 83-90, 2008.

[4] A. Gerber, M. Bundschuh, D. Klingelhofer, and D. A. Groneberg, "Gold nanoparticles: recent aspects for human toxicology," Journal of Occupational Medicine and Toxicology, vol. 8, no. 1, article 32, 2013.

[5] N. I. Hulkoti and T. C. Taranath, "Biosynthesis of nanoparticles using microbes-a review," Colloids and Surfaces B: Biointerfaces, vol. 121, pp. 474-483, 2014.

[6] A. Mishra, M. Kumari, S. Pandey, V. Chaudhry, K. C. Gupta, and C. S. Nautiyal, "Biocatalytic and antimicrobial activities of gold nanoparticles synthesized by Trichoderma sp.", Bioresource Technology, vol. 166, pp. 235-242, 2014.

[7] T. J. Beveridge and R. G. E. Murray, "Sites of metal deposition in the cell wall of Bacillus subtilis," Journal of Bacteriology, vol. 141, no. 2, pp. 876-887, 1980.

[8] P. Mukherjee, S. Senapati, D. Mandal et al., "Extracellular synthesis of gold nanoparticles by the fungus Fusarium oxysporum," ChemBioChem, vol. 3, no. 5, pp. 461-463, 2002.

[9] S. He, Z. Guo, Y. Zhang, S. Zhang, J. Wang, and N. Gu, "Biosynthesis of gold nanoparticles using the bacteria Rhodopseudomonas capsulata," Materials Letters, vol. 61, no. 18, pp. 39843987, 2007.

[10] M. Sastry, A. Ahmed, M. Khan, and R. Kumar, "Biosynthesis of metal nanoparticles using fungi and actinomycete," Current Science, vol. 85, no. 2, pp. 162-170, 2003.

[11] R. Sanghi, P. Verma, and S. Puri, "Enzymatic formation of gold nanoparticles using Phanerochaete chrysosporium," Advances in Chemical Engineering and Science, vol. 1, pp. 154-162, 2011.

[12] D. S. Balaji, S. Basavaraja, R. Deshpande, D. B. Mahesh, B. K. Prabhakar, and A. C. Venkataraman, "Extracellular biosynthesis of functionalized silver nanoparticles by strains of Cladosporium cladosporioides fungus," Colloids and Surfaces B: Biointerfaces, vol. 68, no. 1, pp. 88-92, 2009.

[13] Y. Cui, Y. Zhao, Y. Tian, W. Zhang, X. Lü, and X. Jiang, "The molecular mechanism of action of bactericidal gold nanoparticles on Escherichia coli," Biomaterials, vol. 33, no. 7, pp. 2327-2333, 2012.

[14] J. Y. Song, H.-K. Jang, and B. S. Kim, "Biological synthesis of gold nanoparticles using Magnolia kobus and Diopyros kaki leaf extracts," Process Biochemistry, vol. 44, no. 10, pp. 1133-1138, 2009.

[15] L. Du, L. Xian, and J. X. Feng, "Rapid extra-/intracellular biosynthesis of gold nanoparticles by the fungus Penicillium sp," Journal of Nanoparticle Research, vol. 13, no. 3, pp. 921-930, 2011.

[16] Y. H. Han, B. Zhang, Q. Shen et al., "Purification and identification of two antifungal cyclic peptides produced by Bacillus amyloliquefaciens L-H15," Applied Biochemistry and Biotechnology, vol. 176, no. 8, pp. 2202-2212, 2015.
[17] Y. M. Li, Q. Li, D. K. Hao et al., "Production, purification, and antibiofilm activity of a novel exopolysaccharide from Arthrobacter sp. B4," Preparative Biochemistry \& Biotechnology, vol. 45, no. 3, pp. 192-204, 2015.

[18] M. V. Sujitha and S. Kannan, "Green synthesis of gold nanoparticles using Citrus fruits (Citrus limon, Citrus reticulata and Citrus sinensis) aqueous extract and its characterization," Spectrochimica Acta Part A: Molecular and Biomolecular Spectroscopy, vol. 102, pp. 15-23, 2013.

[19] S. R. Tetgure, A. U. Borse, B. R. Sankapal, V. J. Garole, and D. J. Garole, "Green biochemistry approach for synthesis of silver and gold nanoparticles using Ficus racemosa latex and their $\mathrm{pH}$-dependent binding study with different amino acids using UV/Vis absorption spectroscopy," Amino Acids, vol. 47, no. 4, pp. 757-765, 2015.

[20] D. P. Nelson, D. M. Priscyla, D. Marcela, Y. Alka, G. Aniket, and R. Mahendra, "Mechanistic aspects in the biogenic synthesis of extracellular metal nanoparticles by peptides, bacteria, fungi, and plants," Applied Microbiology and Biotechnology, vol. 90, no. 5, pp. 1609-1624, 2011.

[21] D. Raju, R. Mendapara, and U. J. Mehta, "Protein mediated synthesis of $\mathrm{Au}-\mathrm{Ag}$ bimetallic nanoparticles," Materials Letters, vol. 124, pp. 271-274, 2014.

[22] S. Si and T. K. Manda, "Tryptophan-based peptides to synthesize gold and silver nanoparticles: a mechanistic and kinetic study," Chemistry - A European Journal, vol. 13, no. 11, pp. 31603168, 2007.

[23] S. Kracht, M. Messerer, M. Lang et al., "Electron transfer in peptides: on the formation of silver nanoparticles," Angewandte Chemie-International Edition, vol. 54, no. 10, pp. 2912-2916, 2015.

[24] C. Burda, X. Chen, R. Narayanan, and M. A. El-Sayed, "Chemistry and properties of nanocrystals of different shapes," Chemical Reviews, vol. 105, no. 4, pp. 1025-1102, 2005.

[25] G. R. Salunke, S. Ghosh, R. J. Santosh Kumar et al., "Rapid efficient synthesis and characterization of silver, gold, and bimetallic nanoparticles from the medicinal plant Plumbago zeylanica and their application in biofilm control," International Journal of Nanomedicine, vol. 9, no. 1, pp. 2635-2653, 2014.

[26] P. Jorge, A. Lourenço, and M. O. Pereira, "New trends in peptide-based anti-biofilm strategies: a review of recent achievements and bioinformatic approaches," Biofouling, vol. 28, no. 10, pp. 1033-1061, 2012.

[27] M. Moryl, M. Spętana, K. Dziubek et al., "Antimicrobial, antiadhesive and antibiofilm potential of lipopeptides synthesised by Bacillus subtilis, on uropathogenic bacteria," Acta Biochimica Polonica, vol. 62, no. 4, pp. 725-732, 2015.

[28] A. Shrestha, S. Zhilong, N. K. Gee, and A. Kishen, "Nanoparticulates for antibiofilm treatment and effect of aging on its antibacterial activity," Journal of Endodontics, vol. 36, no. 6, pp. 1030-1035, 2010.

[29] S. Gaidhani, R. Singh, D. Singh et al., "Biofilm disruption activity of silver nanoparticles synthesized by Acinetobacter calcoaceticus PUCM 1005," Materials Letters, vol. 108, pp. 324327, 2013.

[30] S. Ghosh, S. Jagtap, P. More et al., "Dioscorea bulbifera mediated synthesis of novel $\mathrm{Au}_{\text {core }} \mathrm{Ag}_{\text {shell }}$ nanoparticles with potent antibiofilm and antileishmanial activity," Journal of Nanomaterials, vol. 2015, Article ID 562938, 12 pages, 2015. 

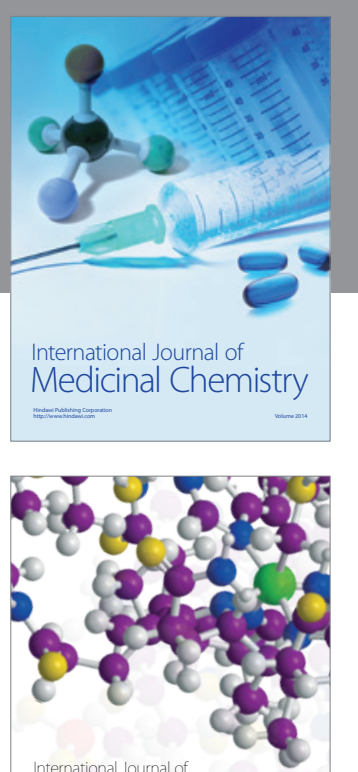

Carbohydrate Chemistry

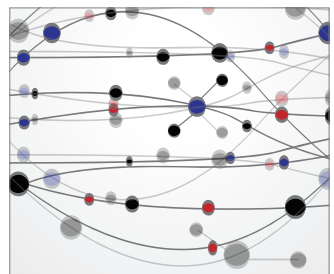

The Scientific World Journal
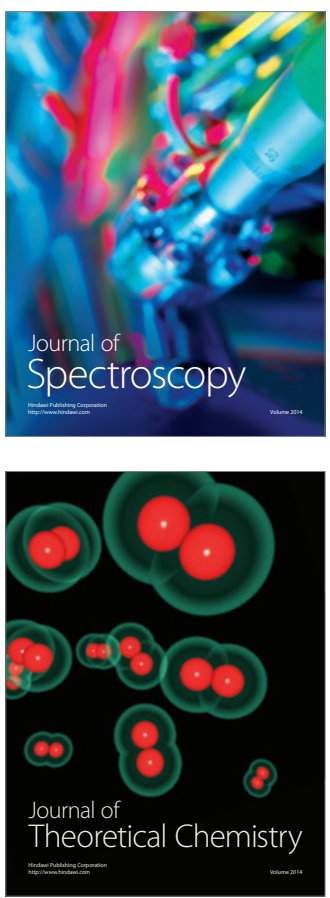
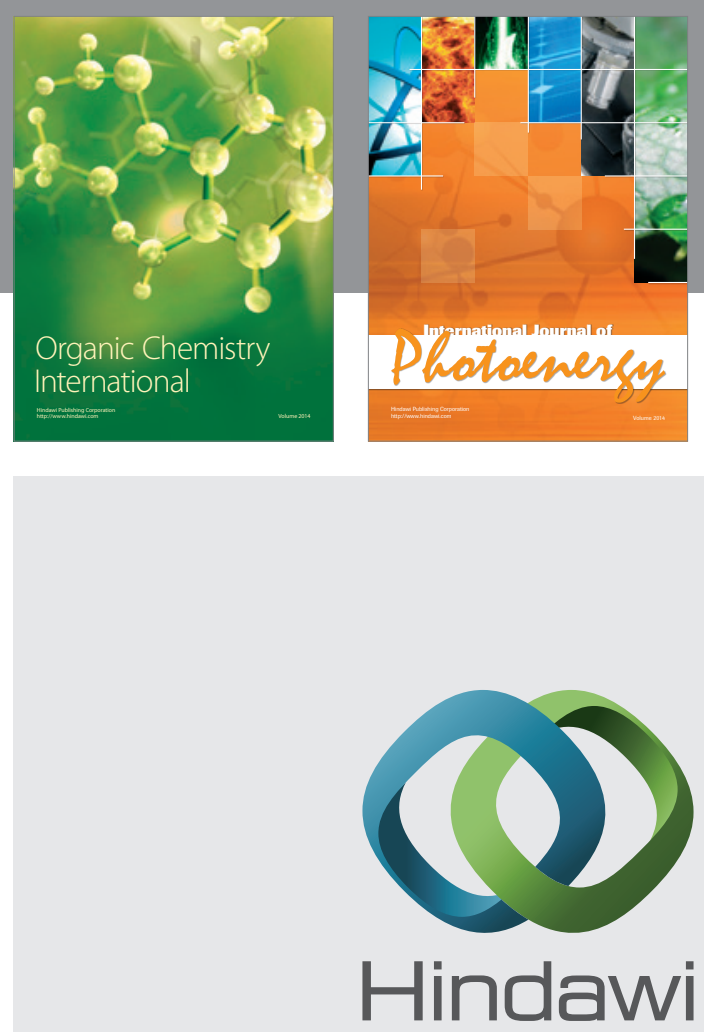

Submit your manuscripts at

http://www.hindawi.com

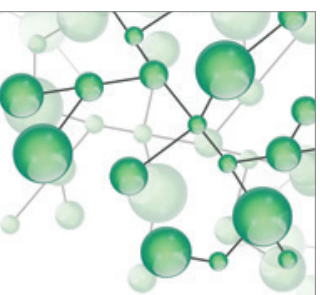

International Journal of

Inorganic Chemistry

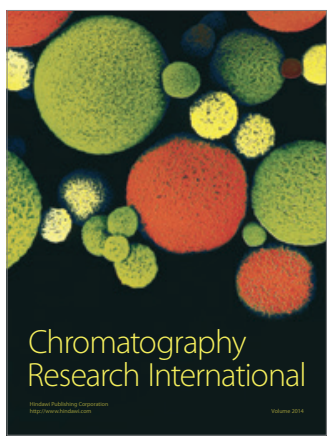

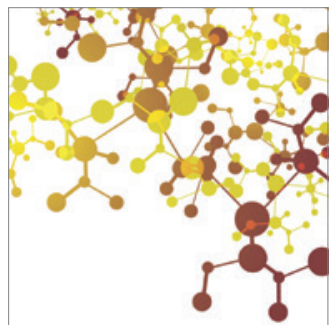

Applied Chemistry
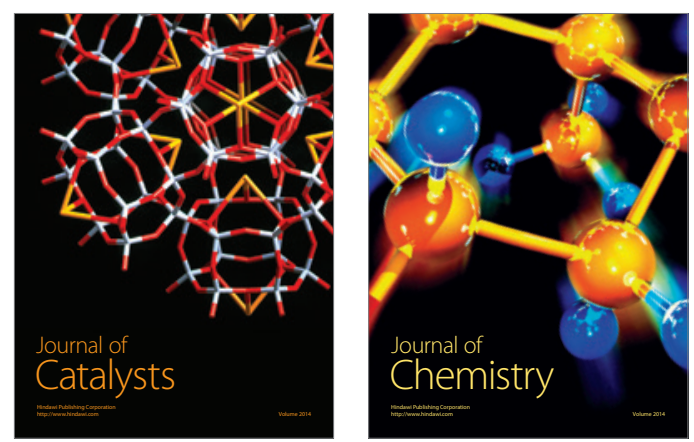
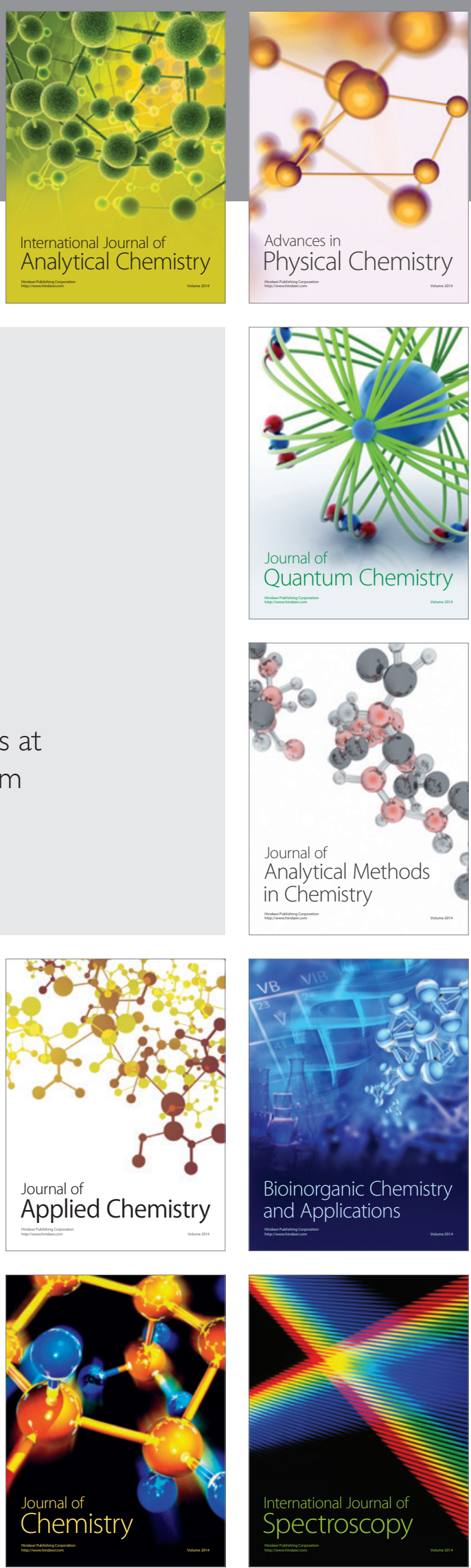